\title{
СТРАТЕГІЧНІ ЗАВДАННЯ ТА ПЕРСПЕКТИВИ РОЗВИТКУ ЦЕНТРІВ ГРОМАДСЬКОГО ЗДОРОВ'Я В УКРАЇНІ
}

\author{
Тернопільський національний медичний університет \\ імені І. Я. Горбачевського МОЗ України, м. Тернопіль, Україна
}

\begin{abstract}
Мета: розробити концептуальні підходи до організації та здійснення стратегічних завдань, визначення перспектив розвитку центрів громадського здоров'я в Україні з урахуванням глобальних викликів і системних змін.

Матеріали і методи. У дослідженні використано такі методи: статистичні, викопіювання статистичних даних, метод експертних оцінок і динамічний аналіз. Роботу було проаналізовано на основі звіту Комунального некомерційного підприємства «Тернопільський обласний центр громадського здоров'я» Тернопільської обласної ради.

Результати. За час фрункціонування Комунального некомерційного підприємства «Тернопільський обласний центр громадського здоров'я» Тернопільської обласної ради проаналізовано питання розбудови системи громадського здоров'я у Тернопільській області. Відповідно до штатного розпису в центрі фуункціонують такі відділи: адміністративно-господарський, інфрормаційно-аналітичний відділ медичної статистики, відділ стратегічного розвитку та матеріально-технічного забезпечення, відділ моніторингу і оцінки, відділ інформаційно-комунікаційної роботи. Проведені аналіз та моніторинг діяльності центру показали наявність загрозливих тенденцій у стані здоров'я населення області. 3 року в рік фріксують зменшення чисельності населення області, зростання показників смертності й захворюваності та зниження рівня народжуваності. Також у роботі шляхом моніторингу чітко визначені стратегічні завдання та перспективи розвитку центрів громадського здоров'я в Україні.

Висновки. Проведений порівняльний аналіз роботи Комунального некомерційного підприємства «Тернопільський обласний центр громадського здоров'я» Тернопільської обласної ради свідчить про негативні тенденції основних показників, що його характеризують. Створення центру надало можливість більш ефективно проводити адресну роботу 3 фрормування у населення області мотивації на здоровий спосіб життя, гігієнічного виховання населення, впровадження у практику роботи медичних закладів профілактичних технологій, спрямованих на збереження та зміцнення здоров'я населення.
\end{abstract}

КЛЮЧОВІ СЛОВА: центр громадського здоров'я; моніторинг; стратегічні завдання; перспективи розвитку.

У сучасних наукових публікаціях стосовно громадського здоров'я народу України наводяться дані, що свідчать про негативні тенденції основних показників, що його характеризують [1, 2, 4, 7].

3 року в рік спостерігається суттєве погіршення стану здоров'я мешканців України. Зростання показників смертності, особливо у працездатному віці, підвищення як первинної, так і загальної захворюваності, низька очікувана тривалість життя порівняно з розвинутими країнами світу, стало свідченням тривожних тенденцій показників здоров'я в Україні.

За визначенням ВОО3, «Громадське здоров'я (Public health) - це наука та практика попередження захворювань, збільшення тривалості життя і зміцнення здоров'я шляхом організованих зусиль суспільства». На сучасному етапі існуючих глобальних викликів громадському здоров'ю, а саме «епідеміологічного зміщення» в бік неінфекційних захворювань, насамперед серцево-судинних, онкологічних захворювань та травматизму, визначено концептуальні підходи щодо вдосконалення стратегічного управління охороною громадського здоров'я в Україні шляхом створення нових структур - центрів громадського здоров'я.

В Україні галузь охорони здоров'я орієнтується на лікування захворювань, а не на їх по- передження. Більшість ресурсів спрямована на лікування хвороби, і лише невелика їх частина передбачає збереження здоров'я $[3,5,6]$.

На сьогодні велику загрозу для жителів нашої країни становить поширеність коронавірусної інфекції, згідно з статистичними даними, на період 2 квітня 2021 р. в Україні налічувалося 1711630 інфікованих хворих, з них померлих 33679 [3]. За останні 10-15 років головною причиною смертності та інвалідності в Україні $€$ велика група таких неінфекційних захворювань, як серцево-судинна патологія, новоутворення та різноманітні зовнішні причини смерті та інші. Великою проблемою $€$ наявність взаємозв'язку високого темпу життя (який включає стреси, малорухливий спосіб життя та проблеми 3 харчуванням) зі зростаючими темпами виходу на інвалідність та високими рівнями смертності людей працездатного віку, що є суттєвою соціально-економічною проблемою для нашої держави.

На сьогодні надзвичайно актуальними є наукові дослідження, спрямовані на встановлення стратегічних напрямків розвитку структур у сорері охорони громадського здоров'я, уніфікованих підходів до оцінки стану здоров'я та його складових, а також обґрунтування шляхів та механізмів впливу на показники здоров'я населення.

(c) Н. Є. Романюк, Л. М. Романюк, П. І. Скобляк, С. С. Рябоконь, 2021 
На особливу увагу заслуговує створення центрів громадського здоров'я. Ці структурні одиниці в системі громадського здоров'я займаються питаннями збільшення тривалості життя, покращення його якості та профрілактикою виникнення захворювань. Існує численна кількість факторів, на які людина може впливати і тим самим збільшувати якість та тривалість життя, а найголовніше своїми діями вона може попереджувати хвороби.

Державна політика у сфері охорони здоров'я в країні повинна ґрунтуватись на вивченні стратегічних напрямків діяльності центрів громадського здоров'я, оскільки зараз нагальними питаннями $€$ вдосконалення стратегічного управління охороною громадського здоров'я в Україні та проведення оцінки ризиків і розв'язання проблем у сорері громадського здоров'я [1-4, 6].

Мета дослідження: розробити концептуальні підходи до організації та здійснення стратегічних завдань, визначення перспектив розвитку центрів громадського здоров'я в Україні з урахуванням глобальних викликів і системних змін.

Матеріали і методи. Розвиток громадського здоров'я в Україні можливий лише в рамках розвитку глобального здоров'я, яке поєднує різноманітні аспекти політики у сфері охорони здоров'я, епідеміології, профрілактики, діагностики й лікування захворювань. Сфера охорони громадського здоров'я України, що існувала до цього часу та була зорієнтована переважно на протидію інфекційним хворобам, перестала відповідати вимогам сьогодення, тому існує нагальна необхідність iii рефрормування. Першочерговим завданням для цього є визначення концептуальних підходів до організаційних засад створення центрів громадського здоров'я.

Необхідно створити таку систему, в якій кожен керівник центрального та місцевого органу виконавчої влади буде враховувати наслідки своїх рішень для здоров'я населення і надавати пріоритет заходам, які допоможуть людям запобігти хворобам і травмам. Розбудова такої системи громадського здоров'я в Україні є однією з вимог Угоди про асоціацію між Україною та Європейським Союзом.

Нова система громадського здоров'я ґрунтується на принципах децентралізації та субсидіарності. Координатором та технічним лідером програм та проектів у цій сфері має стати Центр громадського здоров'я Міністерства охорони здоров'я. Центр має доступ до медичної статистичної інфрормації, здійснює обробку баз даних, готує науково обґрунтовані рішення та аналітику в сорері громадського здоров'я, а також керує обласними установами у цій галузі.

Розвитку центрів громадського здоров'я та впровадженню в них інноваційних технологій сприятиме реалізація політики у сорері громадського здоров'я на регіональному рівні за участю органів місцевого самоврядування. Вони будуть відповідальні за санітарний та епідеміологічний добробут населення, імплементацію Національ- ної стратегії громадського здоров'я на місцевому рівні.

Результати дослідження та їх обговорення. Система громадського здоров'я в Україні розвивається в основних стратегічних сорерах. Отже, в Україні однією зі складових реформи національної системи охорони здоров'я повинна стати розбудова вітчизняної системи охорони/захисту громадського здоров'я на основі створення, фрункціонування та розвитку центрів громадського здоров'я, стратегічним завданням яких $€$ збереження здоров'я населення як загальнонаціонального принципу визнання пріоритетності безпеки в питаннях життя і здоров'я людини.

Роботу було проаналізовано на основі звіту Комунального некомерційного підприємства «Тернопільський обласний центр громадського здоров'я» Тернопільської обласної ради.

У дослідженні використано такі методи: статистичні, викопіювання статистичних даних, метод експертних оцінок і динамічний аналіз.

$\mathrm{Ha}$ виконання розпорядження КМУ наказом МО3 України від 18.09.2015 р. № 604 створено Державну установу «Центр громадського здоров'я Міністерства охорони здоров'я України», на виконання рішення десятої сесії Тернопільської обласної ради шостого скликання від 20.12.2018 р. № 1315 «Про створення Тернопільського обласного центру громадського здоров'я» створено Комунальне некомерційне підприємство «Тернопільський обласний центр громадського здоров'я» Тернопільської обласної ради шляхом реорганізації Інформаційно-аналітичного центру медичної статистики та Центру здоров'я.

Згідно 3 рішенням Тернопільської обласної ради від 20.12.2018 р. № 1315 створено Комунальне некомерційне підприємство «Тернопільський обласний центр громадського здоров'я» Тернопільської обласної ради та відповідно до виписки з Єдиного державного реєстру юридичних осіб, фрізичних осіб-підприємців та громадських формувань 27 червня 2019 р. зареєстровано Комунальне некомерційне підприємство «Тернопільський обласний центр громадського здоров'я» Тернопільської обласної ради.

За час фрункціонування Комунального некомерційного підприємства «Тернопільський обласний центр громадського здоров'я» Тернопільської обласної ради проаналізовано питання розбудови системи громадського здоров'я у Тернопільській області.

Відповідно до штатного розпису в центрі функціонують такі відділи: адміністративно-господарський, інорормаційно-аналітичний відділ медичної статистики, відділ стратегічного розвитку та матеріально-технічного забезпечення, відділ моніторингу і оцінки, відділ інфрормаційно-комунікаційної роботи.

Центр здійснює координацію діяльності та взаємодії закладів охорони здоров'я щодо збору, обробки і аналізу статистичної інфрормації про стан здоров'я населення та ресурси системи охо- 
рони здоров'я, а також проводить збір і аналіз інформації для фрормування регіональної політики та стратегічного управління у сорері громадського здоров'я.

Основні показники, які підлягали аналізу: демографічні показники, показники захворюваності, інвалідності, проводилась оцінка ризиків і розв'язання проблем у сорері громадського здоров'я.

Результати аналізу свідчать про те, що населення області за останні 5 років (2015-2019рр.) зменшилось на 24000 осіб. Рівень народжуваності в області, як і по всій території України, знижується 3 кожним роком. У 2015 р. показник становив 10,1 на 1000 населення, а в 2019 р. - лише 7,6 на 1000 населення. Рівень загальної смертності серед населення коливається 3 року в рік у інтервалі від 14 на 1000 населення (2015-2018 рр.) до 14,3 на 1000 населення, у 2019 р. до 14,1 на 1000 населення.

Показник дитячої смертності також коливався в таких межах (за даний період зменшився 3 7,22 \% на 1000 народжених живими в 2015 р. до 6,27\% на 1000 народжених живими в 2019 р.).

Кількість осіб, які хворіють на активний туберкульоз, на 100000 населення у 2015 р. становила 38,3. За останній період цей показник зменшився і становив 34,4 на 100000 населення у 2019 р.

Захворюваність на онкологічні хвороби за даний період збільшилась. Це пов'язано 3 погіршенням екологічної ситуації, покращенням виявлення онкозахворювань на ранніх стадіях.

У 2015 р. показник осіб, у яких вперше виявлено онкозахворювання, склав 311,0 на 100000 населення. Цей показник коливався протягом даного періоду, і в 2019 р. він становив 334,0 на 100000 населення.

3 питань формування єдиного інформаційного простору в регіоні центр здійснював підготовку та видання довідників і аналітичних оглядів стану здоров'я, ресурсів охорони здоров'я та їх використання в діяльності медичних закладів. Центр проводив організаційно-методичне забезпечення підготовки і проведення акредитації та ліцензування медичних закладів незалежно від відомчого підпорядкування та фрорм власності.

Роботу відділу МіО (моніторингу і оцінки) щодо ефрективного фрункціонування системи моніторингу та оцінки програмних заходів протидії туберкульозу, ВІЛ в області проводили відповідно до Плану реалізації Стратегії розвитку системи протитуберкульозної медичної допомоги населенню Тернопільської області на 2019-2023 рр.

Підрозділом відділу моніторингу і оцінки є сектор імунопрофрілактики.

На сьогодні імунопрофрілактика визнана одним 3 найуспішніших і економічно ефективних заходів у сорері громадського здоров'я. Основними її цілями є збереження здоров'я населення через зниження рівня захворюваності, смертності та інвалідності від інфекційних хвороб, орормування колективного імунітету та зниження витрат системи охорони здоров'я на лікування інфекційних хвороб.
Основна робота сектору полягає в отриманні звітності із закладів охорони здоров'я області, опрацюванні та узагальненні її, відправленні до ДУ «Центр громадського здоров'я Міністерства охорони здоров'я України». Крім того, проводили аналіз виконання запланованих обсягів, планування профрілактичних щеплень на наступні роки та подавали заявку щодо потреби в імунобіологічних препаратах; інформацію за результатами дослідження направляли як на місця до закладів охорони здоров'я, так і до управління охорони здоров'я облдержадміністрації.

У 2020 р. прослідковується чітка тенденція до зниження рівня охоплення профрілактичними щепленнями за рахунок впливу пандемії коронавірусної хвороби. Показники виконання в області щодо більшості нозологій нижчі, ніж за аналогічний період минулого року. Проте за 10 місяців охоплення щепленнями проти кору, паротиту та краснухи дітей у віці 1 рік сягнуло $71 \%$, у 6 років - $73 \%$, проведені щеплення проти гемофрільної інфекції в 1 рік - 81,6 \%.

Важливим розділом профрілактики є фрормування здорового способу життя. Розроблено та затверджено стратегію розвитку та стратегічний план розвитку системи громадського здоров'я. Центром розроблено та затверджено комунікаційну стратегію Комунального некомерційного підприємства «Тернопільський обласний центр громадського здоров'я» Тернопільської обласної ради.

Розроблено проект регіональної програми громадського здоров'я з урахуванням проведеної оцінки. Здійснено фрінансово-економічні розрахунки програми громадського здоров'я. Встановлено План МіО виконання заходів регіональної програми громадського здоров'я.

Розроблено, підготовлено та опубліковано на сторінках соціальних мереж та на веб-сайті матеріали до Всесвітнього дня боротьби проти раку, Міжнародного дня онкохворої дитини, Міжнародного дня рідкісних хвороб, Всесвітнього дня боротьби 3 глаукомою, Всесвітнього і Всеукраїнського дня боротьби проти туберкульозу та багато інших.

У центрі проведено моніторинг медіа-простору в 2019 р.: лютий - 7 публікацій; березень - 6; квітень - 18; травень - 16; червень - 18; липень 46; серпень - 59; вересень - 26; жовтень - 58; листопад - 74; грудень - 10.

Розроблено, видано та поширено друковану продукцію до всесвітніх днів, визнаних ВООЗ: плакат «Туберкульоз», плакат «Онко-скринінг», буклет «СНІД», буклет «Туберкульоз», плакат «Безпечніше уникнути, аніж лікувати» - 1000 екземплярів, плакат «Що робити у випадку захворювання на COVID-19» - 1000, плакат «Педикульоз - профрілактика» - 1000, плакат «Як правильно мити руки» - 1000, плакат «Ознаки інсульту» - 1000, плакат «Грип» - 3000, плакат «ВІЛ/СНІД» - 1000, плакат «Обережно ТЮТЮН» - 1000, плакат «Профрілактика діабету» - 1000, плакат «Вакцинація» - 1000, буклет «Профрілактика гепатиту» - 1000. 
Налагоджена співпраця з такими стейкхолдерами:

1. Тернопільська обласна рада.

2. Тернопільська обласна державна адміністрація.

3. Управління охорони здоров'я Тернопільської обласної державної адміністрації.

4. «ДІА-ДІМ» - Громадська організація «Об'єднання батьків, дітей і молоді Тернопілля, хворих на цукровий діабет».

5. «Іскра надії» - Тернопільська обласна громадська організація хворих на вірусний гепатит С.

6. Тернопільський фонд сприяння розвитку фрізичної культури і спорту.

7. Тернопільська обласна організація Товариства Червоного Хреста України.

8. Громадська організація «Асоціація сімейної медицини Тернопільщини».

9. Громадська організація «Еко-контроль Тернопілля».

10. Громадська організація «Спілка інвалідів «Інтеграція в суспільство».

11. Товариство тверезості та здоров'я.

12. Комунальне некомерційне підприємство «Тернопільський обласний медичний центр соціально-небезпечних захворювань» Тернопільської обласної ради.

13. Комунальне некомерційне підприємство «Тернопільський обласний клінічний онкологічний диспансер» Тернопільської обласної ради.

14. Тернопільська обласна станція переливання крові.

15. Комунальне некомерційне підприємство «Тернопільська обласна комунальна клінічна психоневрологічна лікарня» Тернопільської обласної ради.

16. Комунальне некомерційне підприємство Тернопільська університетська лікарня» Тернопільської обласної ради.

17. ДУ «Тернопільський обласний лабораторний центр МОЗ України».

18. ГО «Джерела громадського здоров'я».

У Центрі громадського здоров'я було організовано та проведено вебінари, фрлешмоби 3 актуальних питань громадського здоров'я:

- вебінар «Коронавірусна інфрекція: фракти проти паніки»;

- вебінар «Здоровий спосіб життя як засіб імунопрофрілактики»;

- вебінар «Здоров'я медиків в епоху епідемії»;

- вебінар «Вірусні гепатити у XXI столітті»;

- фрлешмоб до Всесвітнього дня донора \#яДонор \#яДонорка;

- фрлешмоб «Вакцина діє!»;

- онлайн-вебінар «Гепатити - як вберегтися та як про них говорити»;

- онлайн-вебінар «Пандемія COVID-19 не відміняє рутинної імунізації»;

- онлайн-вебінар «Гігієна рук для контролю інфрекції»;

- онлайн-вебінар «Вакцинація як один 3 важливих аспектів громадського здоров'я»;
- онлайн-вебінар «Чисті руки - запорука здоров'я»;

- онлайн-вебінар «Імунопрофрілактика дорослого та дитячого населення»;

- вебінар «Популяризація громадського здоров'я в ОТГ Тернопілля - обов'язок кожного» (Білецька ОТГ);

- онлайн-вебінар «Шляхи зміцнення здоров'я та благополуччя населення»;

- онлайн-вебінар «Розбудова системи громадського здоров'я на регіональному рівні»;

- онлайн-вебінар «Донорство в період COVID-19»;

- онлайн-вебінар «Серцево-судинні захворювання є однією з провідних причин смерті у світі»;

- онлайн-вебінар «Всесвітній день боротьби зі сказом»;

- онлайн-вебінар «Раціональне використання антибіотиків, боротьба 3 антибіотикорезистентністю»;

- вебінар «Актуальні питання вакцинації, безпека вакцин»;

- акція «Профрілактика серцево-судинних захворювань»;

- робоча зустріч «Популяризація громадського здоров'я в ОТГ Тернопілля - обов'язок кожного» (Великоберезовицька ОТГ);

- онлайн-вебінар «Донорство в умовах пандемії до Всесвітнього дня донорства та трансплантації органів»;

- онлайн-вебінар «Засоби індивідуального захисту для медичних працівників. Гігієна рук медичних працівників»;

- онлайн-вебінар «Що варто знати про вакцинацію від грипу»;

- онлайн-вебінар «Грип, ГPBI, COVID-19: як відрізнити симптоми?»;

- онлайн-вебінар «Про удосконалення проведення профрілактичних щеплень»;

- робоча зустріч «Актуальні питання імунопрофрілактики»;

- онлайн-вебінар «Профрілактика інфрекцій в закладах охорони здоров'я»;

- онлайн-вебінар «Всесвітній день боротьби зі СНІДом (безпечна поведінка та заходи профрілактики ВІЛ/СНІДу)»;

- онлайн-вебінар «Комунікація здорового способу життя засобами соціальних мереж»;

- онлайн-вебінар «Попередження захворюваності на туберкульоз»;

- онлайн-вебінар «Вакцинація - ефективний засіб первинної профрілактики»;

- онлайн-вебінар «Актуальні проблеми громадського здоров'я» для працівників Комунального некомерційного підприємства «Тернопільський обласний центр громадського здоров'я» Тернопільської обласної ради, для відповідальних за імунопрофрілактику окремих лікувально-профрілактичних закладів (списки додаються); 
- онлайн-вебінар «Комунікації у сорері громадського здоров'я»;

- онлайн-вебінар «Епіднагляд за інфрекційними захворюваннями» для працівників Комунального некомерційного підприємства «Тернопільський обласний центр громадського здоров'я» Тернопільської обласної ради, для відповідальних за імунопрофрілактику окремих лікувально-профрілактичних закладів.

Фахівці Комунального некомерційного підприємства «Тернопільський обласний центр громадського здоров'я» Тернопільської обласної ради проводили соціологічні дослідження у вигляді анкетування, тестування щодо вивчення рівня санітарної культури населення області.

У 2020 р. проведено вивчення рівня знань населення 3 питань:

1. Що ви знаєте про здоровий спосіб життя? (для працівників лікувально-профілактичних закладів).

2. Вивчення ролі сім'ї у фрормуванні свідомого ставлення до здоров'я.

3. Що ми знаємо про йододефіцит.

4. Вивчення знань населення щодо профілактики серцево-судинних захворювань.

5. Вивчення поінформованості населення з питань профрілактики сказу.

6. Вивчення поінфрормованості населення про взаємозв'язок куріння та здоров'я.

7. Вивчення обізнаності молоді з питань профрілактики наркоманії.

8. Вивчення знань населення з питань профрілактики грипу, ГРВІ.

9. Вивчення рівня підготовки молодих матерів з питань догляду та вигодовування дітей першого року життя.

10. Вивчення поінформованості населення щодо профрілактики COVID-19.

11. Вакцинація в умовах пандемії.

На базі Комунального некомерційного підприємства «Тернопільський обласний центр громадського здоров'я» Тернопільської обласної ради функціонує «Ліцей здорового способу життя» для населення. У програму ліцею введено семінарські заняття відносно раціонального та дієтичного харчування щодо профрілактики серцевосудинних захворювань, імунопрофрілактики. На практичних заняттях курсантів навчають техніці вимірювання артеріального тиску, наданню першої долікарської допомоги при гіпертонічних кризах, колапсі, зупинці серця. За 2020 р. ліцей відвідало 228 чоловік.

Співробітники відділу стратегічного розвитку та матеріально-технічного забезпечення проводили:

- моніторинг матеріально-технічної бази лікувально-профрілактичних закладів області;

- розробку та впровадження обласної програми енергоефективності та енергозбереження в лікувальних закладах області;

- контроль за підготовкою медичних закладів до роботи в осінньо-зимовий період (заготівля продуктів харчування, палива);
- контроль за резервними джерелами електроживлення і їх готовність до роботи та переведення електроспоживачів на I категорію надійності електроспоживання реанімаційних, операційних, пологових відділень;

- постійний контроль за дотриманням вимог стандартів 3 метрології та правильності виконання вимірювань, використанням і станом засобів вимірювальної техніки та метрологічним забезпеченням діяльності закладів охорони здоров'я;

- розглядали заявки медичних закладів на забезпечення високовартісним сучасним медичним обладнанням, автотранспортом та здійснювали контроль над використанням даного обладнання та експлуатацією автомобілів;

- контроль за дотриманням вимог 3 питань роботи охорони праці, техніки безпеки та пожежної безпеки, атестації робочих місць в лікувально-профрілактичних закладах області;

- навчання 3 питань охорони праці посадових осіб управління охорони здоров'я облдержадміністрації та медичних закладів області;

- роботу в акредитаційних та інших комісіях лікувально-профілактичних закладів області та атестаційних комісіях лабораторій;

- програмно-технічне забезпечення закладів охорони здоров'я, постійне функціонування засобів електронного зв'язку;

- консультативно-методичний супровід інвестиційних програм розвитку.

Таким чином, проведений аналіз діяльності Тернопільського центру громадського здоров'я показав такі стратегічні напрямки та завдання:

- забезпечення пріоритетності здійснення заходів з імунопрофрілактики населення, удосконалення законодавства та забезпечення стабільного фрінансування зазначених заходів;

- забезпечення доступу населення до ефективних, безпечних та економічно обґрунтованих заходів з імунопрофрілактики;

- формування у населення, медичної спільноти і представників державної влади усвідомлення цінності та необхідності імунопрофрілактики і забезпечення соціального попиту на обов'язкові проорілактичні щеплення;

- оптимізація і забезпечення сталого функціонування систем проведення моніторингу та оцінки еорективності заходів з імунопрофрілактики.

Для реалізації стратегічних напрямків діяльності центру передбачається:

- запровадження належного фрінансування заходів $з$ імунопрофрілактики з урахуванням результатів проведеного аналізу наслідків недостатнього рівня охоплення населення щепленнями та формування економічних прогнозів для системи охорони здоров'я та економіки країни загалом;

- визначення потреби в медичних імунобіологічних препаратах (вакцинах) та медичних виробах, які використовують для профрілактичних щеплень, і виконання багаторічних планів заходів щодо проведення профрілактичних щеплень; 
- підвищення еорективності системи закупівлі медичних імунобіологічних препаратів та медичних виробів, які використовують для профрілактичних щеплень, шляхом проведення щорічного аналізу такої системи закупівлі;

- проведення комплексного перегляду та гармонізації 3 міжнародними стандартами нормативно-правових актів, що регулюють питання імунопрофрілактики;

- безперервний моніторинг основних неінфекційних хвороб, які становлять значний тягар для суспільства і спричиняють значні соціально-економічні втрати.

\section{Висновки}

1. Створення Комунального некомерційного підприємства «Тернопільський обласний центр громадського здоров'я» Тернопільської обласної ради надало можливість більш ефективно проводити адресну роботу з формування у населення області мотивації на здоровий спосіб життя, гігієнічного виховання населення, впровадження у практику роботи медичних закладів профрілактичних технологій, спрямованих на збереження та зміцнення здоров'я населення.
2. Проведені аналіз та моніторинг діяльності центру показали наявність загрозливих тенденцій у стані здоров'я населення області. 3 року в рік фріксують зменшення чисельності населення області, зростання показників смертності, захворюваності та зниження рівня народжуваності.

3. Для покращення здоров'я населення необхідно оптимізувати основні стратегічні напрямки діяльності структурних підрозділів центру з метою зниження захворюваності на основні соціально значущі хвороби - серцево-судинні захворювання, злоякісні новоутворення, туберкульоз, травматизм, цукровий діабет, а також зниження рівня смертності.

4. Для досягнення європейських стандартів якості життя та благополуччя населення необхідна координація діяльності Центру громадського здоров'я з усіма гілками влади на базовому, регіональному та державному рівнях.

Перспективи подальших досліджень полягають передусім у поглибленому вивченні стратегічних напрямків роботи системи громадського здоров'я та встановленні нових фрункцій центрів громадського здоров'я.

\section{Список літератури}

1. Грузєва Т. С. Громадське здоров'я (public health) як нова спеціальність: сучасні підходи до викладання (на прикладі Дебреценського університету, Угорщина) / Т. С. Грузєва, Н. В. Гречишкіна, Л. О. Литвинова // Україна. Здоров'я нації. - 2017. - № 1 (42). - С. 166-172.

2. Державна служба статистики України [Електронний ресурс]. - Режим доступу : http://www.ukrstat.gov.ua/.

3. Концепція розвитку системи громадського здоров'я в Україні, схвалена розпорядженням Кабінету Міністрів України від 30 листопада 2016 р. [Електронний ресурс]. - Режим доступу : http://www.kmu.gov.ua/control/uk/caldnpd?/ docid-249618799.

4. Центр громадського здоров'я МОЗ України. Про центр [Електронний ресурс]. - К. : Центр громадського здоров'я МО3 України, 2021. - Режим доступу : https://www.phc.org.ua/pro-centr.

5. Brown C. L. Voting, health and interventions in healthcare settings: a scoping review / C. L. Brown, D. Raza, A. D. Pinto // Public Health Rev. - 2020. - Vol. 41. - P. 16.

6. Galea S. A public health of consequence: review of the February 2017 issue of AJPH / R. Vaughan // Am. J. Public Health. - 2017. - Vol. 107 (2). - P. 203-204.

\section{References}

1. Gruzeva, T., Grechishkina, N., \& Litvinova, L. (2017). Hromadske zdorovya (public health) yak nova spetsialnist: suchasni pidkhody do vykladannya (na prykladi debretsenskoho universytetu, Uhorshchyna) [Public health as a new specialty: modern approaches to teaching (on the example of the University of Debrecen, Hungary)]. Ukrayina. Zdorovya natsiyi Ukraine. The Health of the Nation, 1 (42), 166-172 [in Ukrainian].

2. Derzhavna sluzhba statystyky Ukrayiny [State Statistics Service of Ukraine]. Retrieved from: http://www.ukrstat.gov.ua/ 3. (2016). Kontseptsiya rozvytku systemy hromadskoho zdorovya $v$ Ukrayini, skhvalena rozporyadzhennyam Kabinetu Ministriv Ukrayiny vid 30 lystopada 2016 [The concept of development of the public health system in Ukraine, approved by the order of the Cabinet of Ministers of Ukraine dated November 30, 2016]. - www.kmu.gov.ua. - Retrieved from: http:// www.kmu.gov.ua/control/uk/caldnpd?/docid-249618799

4. (2021). Tsentr hromadskoho zdorovya MOZ Ukrayiny. Pro tsentr. Kyiv: Tsentr hromadskoho zdorovya MOZ Ukrayiny [Public Health Center of the Ministry of Health of Ukraine. About the center. Kyiv: Center for Public Health of the Ministry of Health of Ukraine]. - www.phc.org.ua. - Retrieved from: https://www.phc.org.ua/pro-centr

5. Brown, C.L., Raza, D., \& Pinto, A.D. (2020). Voting, health and interventions in healthcare settings: a scoping review. Public Health Rev., 41, 16.

6. Galea, S., \& Vaughan, R. (2017). A public health of consequence: review of the February 2017 issue of AJPH. Am. J. Public Health., 107(2), 203-204. 
STRATEGIC TASKS AND PROSPECTS OF THE DEVELOPMENT OF PUBLIC HEALTH CENTERS IN UKRAINE

N. Ye. Romaniuk, L. M. Romaniuk, P. I. Skoblyak, S. S. Ryabokon

I. Horbachevsky Ternopil National Medical University, Ternopil, Ukraine

Purpose: to develop the conceptual approaches to the organization and implementation of strategic objectives, identify prospects for the development of public health centers in Ukraine, taking into account global challenges and systemic changes.

Materials and Methods. The following methods were used in the study: statistical, statistical data copying, expert estimation method and dynamic analysis. The analysis of work was carried out on the basis of the report of the municipal non-profit establishment "Ternopil regional center of public health" of the Ternopil Regional Council.

Results. During the operation of the municipal non-profit enterprise "Ternopil Regional Center of Public Health" of the Ternopil Regional Council, the issues of developing the public health system in the Ternopil region were analyzed. According to the staff list, the Center has the following departments: administrative and economic, information and analytical department of medical statistics, department of strategic development and logistics, department of monitoring and evaluation, department of information and communication work. The analysis and monitoring of the center's activities showed the presence of threatening trends in the health of the region's population. From year to year there is a decrease in the population of the region, an increase in mortality and morbidity and a decrease in the birth rate. The strategic objectives and prospects for the development of public health centers in Ukraine are also clearly defined in the work through monitoring.

Conclusions. The comparative analysis of the Ternopil Center for Public Health shows the negative trends in the main indicators that characterize it. The creation of the Ternopil Center for Public Health provided an opportunity to more effectively conduct targeted work on the formation of the population's motivation for a healthy lifestyle, hygienic education, implementation of preventive technologies aimed at preserving and strengthening public health.

KEY WORDS: public health center; monitoring; strategic objectives; development prospects.

Рукопис надійшов до редакції 06.05.2021 р.

\section{Відомості про авторів:}

Романюк Ніна Євгенівна - кандидат медичних наук, доцент, доцент кафедри громадського здоров'я та управління охороною здоров'я Тернопільського національного медичного університету імені І. Я. Горбачевського МО3 України; тел.: +38(0352) 52-72-33.

Романюк Любов Миколаївна - кандидат медичних наук, доцент, доцент кафедри громадського здоров'я та управління охороною здоров'я Тернопільського національного медичного університету імені І. Я. Горбачевського МОЗ України; тел.: +38(0352) 52-72-33.

Скобляк Петро Ігорович - студент 2 курсу медичного фракультету спеціальність «Громадське здоров'я» Тернопільського національного медичного університету імені І. Я. Горбачевського МОЗ України; тел.: +38(0352) 52-72-33.

Рябоконь Світлана Степанівна - кандидат медичних наук, асистент, асистент кафедри первинної медикосанітарної допомоги та загальної практики - сімейної медицини Тернопільського національного медичного університету імені І. Я. Горбачевського МОЗ України; тел.: +38(098) 88-155-45. 